\title{
POLITICAL ECONOMY ANALYSIS IN NON-COMPLIANCE INDONESIA TOWARDS FRAMEWORK CONVENTION ON TOBACCO CONTROL
}

\author{
Hijra Nasir \\ Pascasarjana Hubungan Internasional, Universitas Gadjah Mada \\ Email: hijrahnasir2013@gmail.com \\ UGM
}

\begin{abstract}
This research attempts to analyze the reason or consideration of Indonesian government to not ratify Framework Convention on Tobacco Control (FCTC) yet, in political economy analysis comprises interest of many actors, limitations of capacity of state, the influence of ratification towards Indonesian tobacco trade, FCTC implementation among the Parties, and projection of Indonesia's possibility to comply with this regulation. FCTC has a number of instruments in tobacco control which was arranged by World Health Organization since 1999. This research become necessary due to Indonesia as only one a country in Asia which have not ratified yet, whereas Indonesia has been the fifth biggest of tobacco consumer in the world. It is a qualitative research, where data were collected through interview technique to the certain sources, and other supporting data from books and publication document. It has been analyzed using Chayes concept about compliance and non-compliance with international regulatory agreement consist of ambiguity and lack of capacity, interests, norms, and efficiency. In observing this issue, we can clarify that different interests of actors have become major consideration of Indonesian government to not comply with this convention regarding on the differences priority within ministry, the existence of business actors to influence the decision maker, employment, tobacco farmers, and social cultural aspects. In the forthcoming, there is a possibility that Indonesia will ratify FCTC due to Tobacco Roadmap which is arranged by Ministry of Industry of Indonesia in long-term planning assert that health aspect will be the main priority more than state revenues and employment. In addition, there are a lot of regencies and cities in Indonesia which have been implementing tobacco control regulation. This research, eventually, is expected to provide input analysis to the government in accordance with FCTC.
\end{abstract}

Keywords: Convention on Tobacco Control, non-Compliance, ratify 


\section{INTRODUCTION}

\section{Background}

Indonesia is one of the biggest tobacco producer in the world through production ability $2,2 \%$ of a total production of global tobacco. ${ }^{1}$ As a major producer, controversy of tobacco using in body health has been becoming crucial problem in society. Moreover, by spreading of cigarette harmful for health appears insistence from various parts, including government, world trade organization, and civil society to attempt the comprehensive legal framework in tobacco control. World Health Organization in 1999 commenced to formulate the rules which have legally binding to control tobacco using seriously named Framework Convention on Tobacco Control (FCTC).

FCTC is a convention or treaty in tobacco control as a global agenda which emphasize on reducing tobacco consumption and bringing to a halt. This convention was adopted on May, $21^{\text {st }} 2003$ and effectively applied on February $27^{\text {th }} 2005 .^{2}$ Nowadays there have been 177 countries as the Parties, where 168 countries have signed this convention, 9 countries merely signed but not ratify yet, such as USA, Morocco, Argentina, Switzerland, Cuba, Mozambique, Ethiopia, Haiti, and El Salvador. Surprisingly, in the beginning, Indonesian representatives became an active party which involved in formulating FCTC as they presented in 6 times negotiation forums. In the last time, however, Indonesia refused to sign and ratify and a decade later, Indonesia does not still comply with this convention as one country in Asia and only 8 in the world together with Andorra, Eritrea, Liechtenstein, Malawi, Monaco, Somalia, and Zimbabwe.

A number of study related to this issues have been addressed in many ways. The researches emerge in the pros and cons formulations however tend to focus on certain aspect. Ignatius Mulyono in his writing entitled "Progress Report of Draft Bill in Tobacco Control towards Health Aspect" focus on economy, labor, politic, social cultural aspects that influence government's decision. In the other hand, research conducted by Department of Demography,

\footnotetext{
1 Daeng dkk,Kriminalisasi Berujung Monopoli: Industri Tembakau Indonesia di Tengah Pusaran Kampanye Regulasi Anti Rokok Internasional, Jakarta: Indonesia Berdikari, 2011, page 29.

2 TCSC, 'Policy Paper: Indonesia dan Framework Convention on Tobacco Control”, 2011, page 1.
} 
University of Indonesia and World Bank focus on economic damage and losses due to noncompliance Indonesia in FCTC. Other studies prone to emphasize on the importance of Indonesian government to not ratify FCTC, as demonstrated in Herjuno $\mathrm{Ali}^{3}$ and Daeng, dkk. ${ }^{4}$ In addition, Evi J. Nurifah and Darmadji focus on impact of FCTC in Indonesian tobacco trade prospect. In completing about FCTC controversy, this research focuses on political economy analysis in non-compliance Indonesia.

\section{Purposes and Benefits}

As mentioned in background, this research is conducted to examine the reasons and considerations to not ratify FCTC yet from political economy analysis regarding on the interests of actors, lack of capacity, the influence of ratification on Indonesia tobacco trade, FCTC implementation by the Parties, and projection of possibility to comply with this regulation. This research, eventually, is expected to provide input analysis to the government in accordance with FCTC.

\section{METHODOLOGY}

This research is qualitative as data were collected through a number of interviews to certain interviewers, consist of: Ministry of Trade, Ministry of Health, Ministry of Industry, Non-governmental Organization tobacco control supporter (Tobacco Control Support Center), and World Health Organization Jakarta. Besides, secondary data were collected from books literary and documents as the result of direct researches published by the researchers, nongovernmental organizations, and global organizations.

In defining the factors behind reluctance of Indonesian government to ratify FCTC, we uses concept about the propensity in compliance as proposed by Abram Chayes and Antonia Handler in their books entitled "The New Sovereignty: Compliance with International Regulatory Agreements". The reasons why state does not comply at international agreement is identified by various factors comprise of ambiguity and indeterminacy of treaty language and

\footnotetext{
${ }^{3}$ Herjuno Ndaru, dkk., Tembakau, Negara dan Keserakahan Modal Asing, Jakarta: Indonesia Berdikari, 2012.

${ }^{4}$ Daeng dkk,Kriminalisasi Berujung Monopoli: Industri Tembakau Indonesia di Tengah Pusaran Kampanye Regulasi Anti Rokok Internasional, Jakarta: Indonesia Berdikari, 2011, page 29.
} 
limitations on the capacity of Parties to carry out their undertakings. In the other side, there are three factors that basically cause state to comply in international agreement, such as interests, efficiency, and norms. In this research, those five points will be elaborated to analyze Indonesian government to not ratify Framework Convention on Tobacco Control (FCTC) yet.

\section{RESULTS}

In their conceptual framework, there are factors might be considered "causes" of noncompliance in international agreement as we mentioned in the previous chapter. As a result of an-conformity between interests, norms, and efficiency among the FCTC Parties and Indonesia that this country refuses to comply. Before we discuss these factors, I will provide a brief explanation about the points of non-compliance Indonesia. In some provisions within these regulation, there are still numerous points can't be addressed by Indonesia, though there have been some provision adopted in domestic regulations, particularly in PP 109/2012 about Protection concerning to addictive substances.

\section{Table 1. Point of Non-Compliance Indonesia towards Framework Convention on Tobacco Control}

\begin{tabular}{|c|c|}
\hline $\begin{array}{l}\text { Provision on Framework Convention on Tobacco } \\
\text { Control (FCTC) }\end{array}$ & Points of Non-compliance Indonesia \\
\hline $\begin{array}{l}\text { Price and tax measures to reduce the demand for } \\
\text { tobacco and its products } \\
\text { 1. High importing tax (in tax determination, } \\
\text { the Parties are provided the right to carry } \\
\text { out their structure and tobacco tax system } \\
\text { by considering national circumstances). } \\
\text { This way gives the opportunity to China } \\
\text { or United States apply high importing tax } \\
\text { (for tobacco and its products, respectively } \\
57 \% \text { and } 350 \% \text {, while Canada applies } \\
\text { additional charge to cheroot and tobacco } \\
\text { through federal tax tariff. } \\
\text { 2. High excise tax which applied by the } \\
\text { Parties are } 2 / 3 \text { from total retail price or } \\
\text { approx. } 70 \% \text {. }\end{array}$ & $\begin{array}{l}\text { 1. In Indonesian tariff system stipulated in } \\
\text { Peraturan Pemerintah Menteri Keuangan } \\
\text { 128/PMK.011/2008 about application } \\
\text { import duty upon tobacco products, } \\
\text { importing tax applied for tobacco products } \\
\text { are in } 40 \% \text {. It is much lower than } \\
\text { requirement of FCTC } \\
\text { 2. Excise tax for tobacco products in } \\
\text { Indonesia according to UU No. } 39 / 2007 \\
\text { are } 57 \% \text {. Excise tax, however, in Indonesia } \\
\text { average lower than maximum tariff such as } \\
38 \% \text { in retail price. }\end{array}$ \\
\hline $\begin{array}{l}\text { Protection from exposure to tobacco smoke; a } \\
\text { total of } 96 \% \text { of the Parties reported that they }\end{array}$ & $\begin{array}{l}\text { Even though in PP } 109 / 2012 \text {, protection from } \\
\text { exposure to tobacco smoke has been applied, }\end{array}$ \\
\hline
\end{tabular}




\begin{abstract}
implement measures to protect their citizens from exposure to tobacco smoke by applying a ban (either complete or partial) on tobacco smoking in indoor workplaces and other public places.
\end{abstract}

Packaging and labeling of tobacco products. By providing pictorial warnings on tobacco packages can give the clearer information to consumers (in a number of countries such as Australia, Nepal, Fiji, Ceylon, Thailand, and EU have adopted a law requiring plain packaging of tobacco products (more than $60 \%$ of principal display areas on tobacco packages)

Education, communication, training, and public awareness, implementation on legislative, executive, and effective administration measures)

Comprehensive ban on tobacco advertising, promotion, and sponsorship to reduce tobacco consumption. however its implementation is very weak. Nevertheless, remarkable progress shows numerous regional governments in Indonesia have been applying a ban on tobacco smoking neither indoor workplaces nor other public places.

Indonesia has just adopted the warning pictures of tobacco products in packages only $40 \%$ while FCTC Parties such as Nepal has adopted 90\%.
There is no similar provision on PP 109/2012. It can be concluded that there has no comprehensive regulation yet about providing education, communication, training, and public awareness, implementation on legislative, executive, and effective administration measures that can synergize the reduction consumption on tobacco

On PP 109/2012 only mention that the government will arrange the tobacco advertising control in printed media, broadcasting media, information technology media, and/or outdoor media, and control the tobacco products promotion. Only controlling, not total banning.

There is no similar provision on PP 109/2012
Measures concerning tobacco dependence and cessation; by explaining that each Party involving should attempt to design and implement effective programs, to enter the diagnosis and treatment cost and tobacco dependence, etc.

Reduction of the supply of tobacco

The Parties involving in FCTC required to eliminate all forms of illicit trade in tobacco products.

Tobacco growing and support for economically viable alternatives; each Party work together with other Party and international organization to promote for economically alternative activities for labors, farmers, and tobacco retailer.
There is no similar provision on PP 109/2012 and other related regulations, so that we can find many practices of illicit trade on tobacco products in Indonesia

Cooperation between central and regional government to boost the research development concerning on pacification addictive substance in tobacco products for health purpose and to enhance tobacco products diversification. 


\section{Ambiguity}

Ambiguity concept related to indeterminacy on the treaty language that occur multiinterpretation to explain within which it is difficult tp say with precision what is permitted and what forbidden. Explicit provision in FCTC which are identified contains ambiguity, such as: the agreement allows the exceptional towards ban on total advertising for countries with constitutional difficulties. Language haziness obviously is about "constitutional difficulties" itself. Nevertheless, Article 6 concerns to encourage price and tax measures increase to reduce the demand for tobacco. In this provision is asserted that a Party may enter prohibitions and restrictions in sales or to import the tobacco product by free duties. These language treaty seems to have ambiguous meaning due to the word of "may" and not "require" as other provisions in FCTC. On the other hand, there are no guidelines for this provision that can interpret the meaning of this agreement specifically.

\section{Limitation of Capacity}

In Indonesia case, a number of factors identified as obstructions to comply with FCTC due to limitation of capacity, consist of:

1. Tobacco control issues are not be seen as priority issues to non-health institutions. We can find obviously that government institutions beyond health ministry don't consider tobacco control as priority issue referring to their reluctance to ratify FCTC. As results from the lack of political supports and weak coordination between sectors in government cause this parties find difficulties to link up their opinions concerning FCTC ratification.

2. Insufficient support from legislatives. Indonesian law makers seems to be reluctant to ratify FCTC due to consider that Indonesia had have PP 109/2012. On the contrary are discussing draft bill on tobacco control which is considered as contrary with FCTC provisions due to propensity in protecting the cigarette companies.

3. Lack of public awareness. It is related to lack of comprehensive and integrated tobacco control programs to provide the education to the society about the danger of cigarette consumption and insufficient coordination in public education program. Smokers habit that disregard the prohibition "no smoking warning" in public places, retailers who sell 
their tobacco products to children and pregnant women; and smoker behavior as the result poor awareness.

4. The influence of tobacco industries has been becoming the main reason why Indonesia doesn't comply to FCTC. The large pressures of tobacco industries large scale towards decision makers cause government refuse to ratify. Intervention by tobacco company we can find in Indonesia and Australia case in Dispute Settlement Body (DSB) WTO concerning plain packaging measures by Australia. The tobacco industry continues to use legal challenges to tobacco control measures to prevent, delay, or weaken implementation of those measures.

5. Limited expertise, either in health researches or development in tobacco leaves using; lack of data; weak monitoring; discrepancies between policies and the implementation guidelines adopted by the COP, and lack of research systems; difficulties in enforcing smoke-free measures or lack of national testing capacity to comply in FCTC.

Three factors which identified by Chayes as state's reasons to comply with international regulatory, consist of: interests, norms, and efficiency. These factors can explain explicitly about the consideration of Indonesia to not ratify FCTC.

\section{Interests}

In this research, aspects analyzed regarding on interests are in-harmonization between actors in influencing decision makers about the importance of FCTC ratification for Indonesia. There are numerous state and non-state actors in this complex issue. This research focuses on examining the interests of certain ministry as state actors to take their positions. Ministry of Health put up a good fight to ensure the government to ratify and adopt this regulations meet "blind alley" due to the efforts of other institutions, such as: Ministry of Industry, Ministry of Trade, Ministry of Agriculture, and Ministry of Public Works have different considerations where they affirm that tobacco is not merely concerning on health aspect, but also workforces, industry, tax and duty, farmer protection which will affect social economy problems in Indonesia.

The major consideration of Ministry of Industry doesn't comply with FCTC due to consider that tobacco manufacture industries have been playing the important role to actuate 
national economy. Those industry have wide multiplier effect to boost economy, such as: state revenues, growing related service industries, equipping workplaces and employment absorption approximately 6,1 million labors, particularly in tobacco producer areas, cloves, and cigarette fabrics. $^{5}$

Table 2. The Development of Cigarette Industries, Production, and Tax Revenues (2007-2013)

\begin{tabular}{|l|l|l|l|l|}
\hline No. & Year & Cigarette Industries & $\begin{array}{l}\text { Productions } \\
\text { (Billion stick) }\end{array}$ & $\begin{array}{l}\text { Tax Revenues } \\
\text { (Quintillion Rp.) }\end{array}$ \\
\hline 1. & 2007 & 4.793 & 231 & 43,5 \\
\hline 2. & 2008 & 3.961 & 240 & 49,9 \\
\hline 3. & 2009 & 3.225 & 286 & 54,4 \\
\hline 4. & 2010 & 2.600 & 302 & 63,3 \\
\hline 5. & 2011 & 2.540 & 312 & 73,3 \\
\hline 6. & 2012 & 1.000 & 326,8 & 90,6 \\
\hline 7. & 2013 & 800 & 341 & 103,6 \\
\hline
\end{tabular}

Source: Director General of Tax, GAPPRI

According to Ministry of Trade, the impact of international pressure on tobacco control doesn't give direct influence in Indonesian tobacco trade, especially export of tobacco and its products because of a fact that these regulations prevail in domestic, not export restriction.

Table 3. Realization on Indonesia Tobacco Products Export (2004-2014)

\begin{tabular}{|l|r|r|}
\hline Year & Value & \multicolumn{1}{|c|}{ Volume $(\mathrm{Kg})$} \\
\hline 2004 & 257.240 .369 & 80.155 .652 \\
\hline 2005 & 323.742 .296 & 91.604 .229 \\
\hline 2006 & 339.776 .158 & 96.854 .028 \\
\hline 2007 & 424.720 .602 & 95.993 .062 \\
\hline 2008 & 508.804 .893 & 111.617 .488 \\
\hline 2009 & 595.608 .953 & 110.906 .027 \\
\hline 2010 & 672.596 .951 & 117.158 .007 \\
\hline 2011 & 710.070 .143 & 99.485 .228 \\
\hline 2012 & 794.176 .252 & 106.382 .344 \\
\hline 2013 & 931.385 .515 & 117.542 .868 \\
\hline $2014 *$ & 1.306 .380 .229 & 158.754 .985 \\
\hline
\end{tabular}

Source: BPS, Center of Data and Information, Ministry of Trade RI (elaborated by author) *data January-August 2014

\footnotetext{
${ }^{5}$ Directorate of Drinking and Tobacco Industry, Ministry of Industry. Pointers Bahan Wawancara tentang Aksesi Framework Convention on Tobacco Control. Jakarta: Kementerian Perindustrian, 2014.
} 
Table 3 demonstrates that in the recent ten years (2004-2014), Indonesia tobacco export have been experiencing fluctuation, nevertheless, surprisingly increase. From 2013 to 2014 it increased dramatically an appropriation of US\$ 374.994.714. ${ }^{6}$ in the other hand, tobacco imports increase rapidly during this period.

Table 4. Realization on Indonesia Tobacco Products Import (2004-2014)

\begin{tabular}{|l|r|r|}
\hline \multicolumn{1}{|c|}{ Year } & Value & \multicolumn{1}{c|}{ Volume (Kg) } \\
\hline 2004 & 171.105 .612 & 43.362 .482 \\
\hline 2005 & 180.353 .006 & 48.419 .266 \\
\hline 2006 & 191.263 .748 & 54.909 .114 \\
\hline 2007 & 267.794 .339 & 69.867 .964 \\
\hline 2008 & 401.441 .192 & 87.325 .984 \\
\hline 2009 & 365.770 .230 & 63.688 .234 \\
\hline 2010 & 470.538 .391 & 78.300 .482 \\
\hline 2011 & 591.716 .793 & 117.126 .096 \\
\hline 2012 & 765.562 .417 & 151.145 .491 \\
\hline 2013 & 723.571 .997 & 135.264 .627 \\
\hline $2014^{*}$ & 879.392 .257 & 157.791 .549 \\
\hline
\end{tabular}

Source: BPS, Center of Data and Information, Ministry of Trade RI (elaborated by author) *data January-August 2014

This figure shows that tobacco import values prone to be fluctuation thorough a decade. Since 2004 to 2014 regrettably import on tobacco products rose steeply from US\$171,105,612 in 2004 to US\$ $171,105,612$ in 2014. These escalation are triggered by the increase of domestic tobacco production that need the huge tobacco leaves supply, for instance to white cigarette production that need Virginia leaves in a large quantity, whereas domestic stock are insufficient to this kind of tobacco leaves.

Other factor contributed to import increase, due to import duty-free and tax, liable apply in Indonesia are too low comparing with other countries that ratify in FCTC. In this agreement, one of effort to reduce tobacco consumption by increasing price and tax. Nonetheless Indonesia is levying import duty for cigarettes in 40\%, much lower than USA (350\%) and China (57\%). Indonesia tariff policy are stipulated on Peraturan Menteri Keuangan No. 128/PMK.011/2008 about fulfillment of import duty at tobacco products. ${ }^{7}$

\footnotetext{
${ }^{6}$ BPS, Center of Data and Information, Ministry of trade RI, 2014

${ }^{7}$ Daeng, dkk, Op.Cit, page 41
} 
On the other side, Ministry of Health is the most active institution to encourage FCTC ratification. These attempts obviously related to health consideration, where Indonesia is a state with fifth highest prevalence in tobacco consumption in the world, after China, USA, Russia, and Japan. ${ }^{8}$ Take into consideration, we need the comprehensive regulation to control tobacco consumption and the disease caused by smoking by ratifying FCTC.

The disadvantages of non-compliance to FCTC :

1. Indonesia becomes the market of cigarette multinational industry that can damage the health of this nation generation and quality of Indonesian human resources.

2. Indonesia doesn't have the opportunity to join Conference of party to strive for our national interest and involving in negotiation of FCTC guidelines and protocol implementation.

3. Cigarette consumptions will be increase steeply, particularly in minor (young people, pregnant women, and poor families) that increase disease and death related to cigarette consumption.

4. Indonesia lost its dignity and prestige as a state that protect and responsible to enhance the health societies degree.

Except the government institutions, one of main actor which have bargaining power to influence FCTC ratification is tobacco industry. They are a party which will have financial loss if FCTC ratified due to consumption reduction. According to data collected by Bursa Efek Jakarta (BEI) in 2009, until quarterly I 2009, the major companies holding Indonesian tobacco market, consist of:

1. HM. Sampoerna 24,3\% (down to quarterly I 2008 approx. 25\%)

2. Gudang Garam 21,1\% (down to quarterly I 2008 approx. 22,5\%)

3. Djarum 19,4\% (up to quarterly I 2008 approx. 19,4\%)

4. Nojorono 6,7\% (up to quarterly I 2008 approx. 6,4\%)

5. Bentoel 6\% (up to quarterly I 2008 approx. 5,7\%)

6. Philip Morris Indonesia 4,7\% (up to quarterly I 2008 approx. 4,5\%)

7. BAT Indonesia $2 \%$ (down to quarterly I 2008 approx. 2,5\%)

${ }^{8}$ WHO, 2008 
8. Lain-lain $15,8 \%$ (up to quarterly I 2008 approx. 15,6\%)

FCTC also has regulation concerning comprehensive ban on tobacco advertising, promotion, and sponsorship. However as a result of non-compliance Indonesia towards FCTC, tobacco companies have discretion to undertake promotion, advertising, and sponsorship freely that positioning Indonesia with Cambodia as two countries which still absolve cigarette sponsorship in sport event, music concert, street party, etc.

Other actor who plays important role in FCTC is tobacco farmers. They are always to be the reason of government and private actor, and become the actor who always been moved to undertake the demonstration in FCTC rejection. Nonetheless, they have weak bargaining position causing the price of their harvest is determined by the grader that farmers only trapped in tobacco industry circle which less profitable for them.

In agriculture sector, the contribution of tobacco and cloves commodity as main substance are relatively insignificant to the total of agriculture and horticultural sector in Indonesia, respectively $1,54 \%$ and $2,83 \%$ toward horticultural product values, whereas towards agriculture product values only $0,27 \%$ for tobacco and $0,49 \%$ for cloves. It is accordance with small contribution plant areal and the quantity of tobacco farmers in Indonesia. Tobacco land areal reach 198 thousand hectares (approx. 0,9\% of national horticultural land areal), nevertheless the amount of farmers who involving directly in tobacco farming only 554,5 thousand farmer households or amount $8,0 \%$ than horticultural households reach 6.880 households, or only $2,1 \%$ of total agriculture households amount 25.579 households. ${ }^{9}$

Table 5. Tobacco, Cloves, and Cigarette Industry Contribution toward Indonesia Gross Domestic Product (GNP), 2005

\begin{tabular}{|c|c|c|c|c|}
\hline \multirow[b]{2}{*}{ Sector } & \multirow[b]{2}{*}{$\begin{array}{l}\text { Values } \\
\text { (Million } \\
\text { Rupiah) }\end{array}$} & \multicolumn{3}{|c|}{ Percentage (\%) } \\
\hline & & $\begin{array}{l}\text { to Total } \\
\text { GDP }\end{array}$ & $\begin{array}{l}\text { to Total Agro- } \\
\text { Industry }\end{array}$ & $\begin{array}{c}\text { to tobacco } \\
\text { Agribusiness }\end{array}$ \\
\hline Tobacco & 1.043 .243 & 0,03 & 0,31 & 2,18 \\
\hline Cloves & 1.920 .290 & 0,07 & 0,57 & 4,02 \\
\hline cigarette industry & 44.783 .773 & 1,56 & 13,33 & 93,80 \\
\hline Cigarette agribusiness & 47.747 .306 & 1,66 & 14,21 & 100,00 \\
\hline
\end{tabular}

\footnotetext{
${ }^{9} \mathrm{BPS}, 2008$
} 


\begin{tabular}{|l|r|r|r|l|}
\hline total agro industry & 335.850 .665 & 11,67 & 100,00 & \\
\hline Total GDP 2005 & 2.876 .891 .630 & 100,00 & & \\
\hline
\end{tabular}

Source: elaborated by Santoso et al (2009) based on data table I-O 2005

\section{Norms}

Norms concerning on non-compliance Indonesia is how these rules in society regarding the danger of tobacco using for human health defines its formulation through involvement a number of civil society in boosting FCTC ratification through great quantities of effort to influence the decision making. One of civil society which is consistently strive for FCTC ratification is Tobacco Control Support Center (TCSC) which actively spread out information about this issue and undertake various cooperation with other institution, such as WHO, Ministry of Health, NGO, and society.

\section{Efficiency}

Efficiency is considered as a reason for state to adopt available international agreement into domestic legislation, as a result to save the cost of drafting the new domestic regulation. Towards to FCTC ratification, Indonesia is prone to not comply with this agreement not because of consideration to efficiency. It seems that legislatives are still reluctant, as the contrary they have been discussing tobacco draft bill as an agenda in Prolegnas.

\section{FCTC Implementation by the Parties}

FCTC contains a number of instruments asserting the importance to reduce demand and supply of tobacco. These following provision as attempt to reduce the demand of tobacco as explained in Article 6-14, consist of:

1. Price and tax measures to reduce the demand for tobacco,

2. Non-price measures comprises:

1) Protection from exposure to tobacco smoke,

2) Regulation of the contents of tobacco products,

3) Regulation of tobacco product disclosure,

4) Packaging and labeling of tobacco products,

5) Education, communication, training, and public awareness, 
6) Tobacco advertising, promotion, and sponsorship

7) Demand reduction measures concerning tobacco dependence and cessation.

In addition, provisions on supply reduction as stipulated in Article 15-17 comprise:

1) Illicit trade in tobacco product,

2) Sales to and by minors,

3) Provision of support for economically viable alternative activities.

Other attempt are conducted by WHO in supporting tobacco control measures named MPOWER program, consist of:

Monitor tobacco use and prevention policies

Protect people from tobacco use

Warn about the dangers of tobacco

Enforce bans on tobacco advertising, promotion and sponsorship

Raise taxes on tobacco

Even though Indonesia doesn't ratify FCTC yet, WHO always attempts to boost this such program in cooperation with Ministry of Health, NGO, and universities to enhance the attempt to control tobacco epidemic in Indonesia.

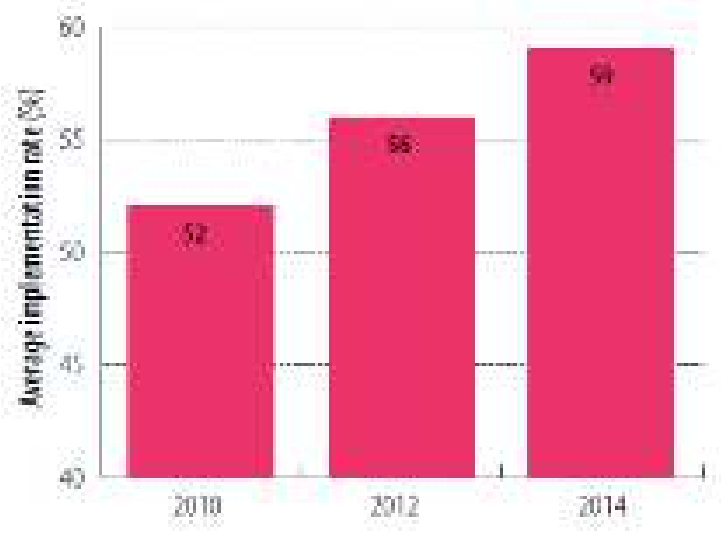

Figure 1. Implementation rate of the WHO FCTC across all comparable indicators, 2010-2014

Source: Global Progress Report, WHO, 2014 
This figure presents the implementation rates of substantive measures by the Parties. In 4 years only, the implementation of the treaty, when calculated by indicators comparable across all reporting cycles, increased steadily from $52 \%$ by 2010 and $56 \%$ in 2012 to $59 \%$ in $2014 .{ }^{10}$

\section{Projection on Indonesian Compliance to Framework Convention on Tobacco Control (FCTC)}

Even though FCTC ratification still invites numerous controversy domestically, but the author forecast that Indonesia will ratify this treaty in forthcoming years. A number of factors referring to this projection due to policy of government itself to arrange more strict regulation concerning tobacco control, comprises of through excise tax periodically to increase country's revenues and to control consumption; by putting the tobacco company as negative industry due to the presence of prohibition to build new company unless it affiliates with available cigarette company; production capacity will be limited only 260 billion sticks in 2020 . These instruments as some proof that Indonesia may be will comply this regulations in the upcoming years. By ratifying this treaty, Indonesia will have the chance as participant in every negotiation on Conference of Party to strive for our national interests in FCTC guidelines and protocol implementation. Moreover, the pressure from many countries and other parties become stronger to encourage Indonesia as one and only state in Asia doesn't ratify this convention.

According to Public Relations Department, Ministry of Industry, in Tobacco Product Industry Roadmap 2007-2020, medium term aspect (2010-2015) is prioritizing to state revenues and labors more than health aspect. However, in long term purpose (2015-2020) of this roadmap will be prioritizing health aspects more than other aspects. ${ }^{11}$ Hence, there will be possibility to Indonesia complies in this convention.

Other reason as Indonesian propensity to comply with FCTC is increase of large number of regional/cities in implementing free-smoking area reach 127 regions/cities. ${ }^{12}$ By rising the

\footnotetext{
${ }^{10}$ Dr Tibor Szilagyi. 2014 Global Progress Report on Implementation of The WHO Framework Convention on Tobacco Control. Geneva: World Health Organization, 2014.

${ }^{11}$ Pemerintah Akan Tandatangani FCTC Tahun 2020, http://m.beritasatu.com/kesra/187161-pemerintah-akantandatangani-fctc-tahun-2020.html accessed on June, $18^{\text {th }} 2015$ 2:39 WIB

${ }_{12}$ Ditanya Soal FCTC Presiden Masih Diam, http://m.beritasatu.com/nasional/280734-ditanya-soal-fctcpresiden-masih-diam.html accessed on June, 19th 2015 at 23:48 WIB
} 
awareness of regional government to implement this instrument demonstrates that in the forthcoming years, there are many regional governments apply this instrument in their domestic legislation. Moreover, the involvement of civil society are tend to be larger and stronger to urge the decision maker can be a sign to reinforce this projection.

The government, nevertheless, need to undertake numerous efforts to protect some parties from material injuries causes of this ratification, such as tobacco and cloves farmers, cigarette industries, workers, advertising industry, and other related industry. A number of strategies need to be prepared by Indonesian government as mentioned in previous chapter, need strong and comprehensive commitment from various parties, especially Ministry of Agriculture. A small number of endeavor comprise: 1) enhancing the researches concerning tobacco leaves using beyond cigarette substance, for example as pesticide or medicines substances. After those researches, we need to socialize this innovation to farmers and industry massively to commence producing this kind of things in large scale, 2) diversion of tobacco farmer or fabric labor to search other occupation, 3) land conversion from tobacco farming to other commodity which can provide them more profit and more stable, 4) providing comprehensive and integrated education to the society about the effect of tobacco consumption. In the future, Dana Bagi Hasil Cukai (DBHC) $)^{13}$. DBHC can be used to undertake above strategies effectively.

\section{REFERENCES}

Abdillah Ahsan, dkk., "Illicit Cigarettes in Indonesia", publiced by Demographic Institute Faculty Of Economics, University Of Indonesia and Southeast Asia Tobacco Control Alliance, pg. 2

Abram Chayes, Antonia H. Chayes, The New Sovereignty: Compliance With International Regulatory Agreement, London: Harvard University Press Cambridge, Massachusetts, 1995, pg. 3-6

Albuja, S.; Daynard, R.A. The Framework Convention on Tobacco Control and the adoption of domestic tobacco control policies: The Ecaudorian experience. Tob. Control 2009, 18, $18-21$.

\footnotetext{
${ }^{13}$ States revenues from excise tax for each tobacco producer region as compensation to protect society in health aspect, as well as to increase the productivity of farmers and tobacco industry.
} 
Assunta, M.; Chapman, S. Health treaty dilution: A case study of Japan's influence on the language of the WHO Framework Convention on Tobacco Control. J Epidemiol. Commun. Health 2006, 60, 751-756.

Chaloupka F, Corbett M., "Trade policy and tobacco: towards an optimal policy mix", in:

Abedian L, Van Der Merwe R, Wilkins N, Jha P, editors. The Economics of Tobacco Control: Towards an Optimal Policy Mix. Cape Town, South Africa: Applied Fiscal Research Centre, University of Cape Town; 1998.

Daeng dkk, Kriminalisasi Berujung Monopoli: Industri Tembakau Indonesia di Tengah Pusaran Kampanye Regulasi Anti Rokok Internasional, Jakarta: Indonesia Berdikari, 2011, hlm. 29.

Direktorat Industri Minuman dan Tembakau, Kementerian Perindustrian. Pointers Bahan Wawancara tentang Aksesi Framework Convention on Tobacco Control. Jakarta: Kementerian Perindustrian, 2014.

Dr Tibor Szilagyi. 2014 Global Progress Report on Implementation of The WHO Framework Convention on Tobacco Control. Geneva: World Health Organization, 2014.

Evi Nurifah J. dan Darmadji, "Prospek Pasar Tembakau Jawa Timur”, Jurnal Widya Agrika diterbitkan oleh Fakultas Pertanian Universitas Widyagama Malang Volume 1, Nomor 2, Agustus 2003, hlm. 80.

Fact sheet Fakta Tembakau di Indonesia, TCSC IAKMI, 2014

Fact sheet Mengapa Indonesia Perlu Mengaksesi FCTC, Kementerian Kesehatan RI, 2013

FAO, 2011 http://faostat.fao.org/site/342/default.aspx, (diakses Desember 2011)

Framework Convention Alliance. FCA Membership Directory. Available online:

http://www.fctc.org/index.php?option=com_sobi2\&catid=8\&Itemid=26 (diakses 27 Februari 2012)

Grüning, T.; Weishaar, H.; Collin, J.; Gilmore, A.B. Tobacco industry attempts to influence and use the German government to undermine the WHO Framework Convention on Tobacco Control. Tob. Control 2012, 21, 30-38.

Hakim, Ari Rahmat. Pengusahaan Tembakau Virginia di Lombok. Undergraduate Thesis, Semarang: UNDIP, 2010.

Hasbullah Thabrani, dkk. Rokok Mengapa Haram? : Bunga Rampai Lomba Anti Rokok . Jakarta: Unit Pengendalian Tembakau FKM-UI, 2013. 
Herjuno Ndaru, dkk., Tembakau, Negara dan Keserakahan Modal Asing, Jakarta: Indonesia Berdikari, 2012.

Ignatius Mulyono, “ Perkembangan RUU tentang Pengendalian Dampak Produk Tembakau Terhadap Kesehatan", makalah disampaikan dalam Executive Forum in low- and middle-income countries", Health Policy and Planning Advance Access, published May, 13 2012, Oxford University Press in association with The London School of Hygiene and Tropical Medicine Health Policy and Planning 2012;1-11, p. 1.

Innovative Medicines South Africa (IMSA). In Referencing Pricing-Background Informtion and IMSA Position; IMSA: Houghton, South Africa, N.D; pp. 1-4. Available online: http://www.imsa.org.za/files/Library/IMSA\%20Position\%20Statements\%20and\%20Is sues(1)/IM SA\% 20Position\%20on\%20Reference\%20Pricing.pdf (accessed on 8 March 2012).

Jakkson, Robert, and Georg Sorensen. Pengantar Studi Hubungan Internasional; Teori dan pendekatan Edisi Kelima. New York: Oxford University Press Inc., 2013.

Jeanne Adiwinata Pawitan, "Tobacco control policy in Indonesia: Editorial 215 Vol.19, No.4, November 2010", Department of Histology, Faculty of Medicine, University of Indonesia.

Jesse B Bump, Michael R. Reich, "Political economy analysis for tobacco control language of the WHO Framework Convention on Tobacco Control. J Epidemiol. Commun. Health 2006, 60, 751-756.

Lin, V. The Framework Convention on Tobacco Control and health promotion: strengthening the ties. Global Health Promotion 2010, 17, 76-80.

Lovato C, Linn G, Stead LF, Best A. Impact of Tobacco Advertising and Promotion on Increasing Adolescent Smoking Behaviors. Cohrane Database Syst Rev. 2003; (4);CD003439.

Mamadu, H.M.; Glantz, S.A. Civil society and the negotiation of the Framework Convention on Tobacco Control. Glob. Public Health 2009, 4, 150-168.

Mamadu, H.M.; Hammond, R.; Glantz, S.A. International trade versus public health during the FCTC negotiations, 1999-2003. Tob. Control 2011, 20, 1-10.

Media Indonesia dengan topik Pembahasan Rancangan Undang-Undang Tembakau di Indonesia di Millennium Hotel, Jakarta, 28 Juli 2011, diakses melalui 
http://www.dpr.go.id/complorgans/baleg/makalah_PERKEMBANGAN_RUU_TENT ANG_PENGENDALIAN_DAMPAK_PRODUK_TEMBAKAU_TERHADAP_KES EHATAN_Oleh__Ignatius_Mulyono.pdf tanggal 20 Mei 2014

Mohamad, Kartono, TCSC, interviewed by Hijrah Nasir. Keterlibatan LSM dalam Kampanye Pengendalian Tembakau (Desember 3, 2014).

Naskah Framework Convention on Tobacco Control, 2003.

Philip Morris International. Morgan Stanley Global Consume and Retail Conference. 2008 Nov 18. New York City, USA. Available from: http://www.philipmorrisinternational.com/global/media/PC/FINAL_11-1808_Morgan_Stanley_website_distribution_slides[1].pdf

Press Release World No Tobacco Day, diakses dari http://bem.fk.ugm.ac.id/2014/05/maknaseruan-world-no-tobacco-day-bagi-indonesia/ tanggal 17 Mei 2015 pukul 02:54 WIB

Rahmat, Muchjidin, dan Sri Nuryanti. "Dinamika Agribisnis Tembakau Dunia dan Implikasinya bagi Indonesia." Forum Penelitian Agro Ekonomi Volume 27 No.2 , 2009: 73-91.

Soegijanto Padmo, dkk., Tembakau: Kajian Sosial Ekonomi, Yogyakarta: Aditya Media, 1991, hlm. 15 .

Siti Komariah, Direktorat Industri Minuman dan Tembakau, Kementerian Perindustrian, interviewed by Hijrah Nasir. Pertimbangan Kementerian Peridustrian Menolak Aksesi FCTC (February 17, 2015).

Siti Komariah, Direktorat Industri Minuman dan Tembakau, Kementerian Perindustrian, interviewed by Hijrah Nasir. Penyebab Peningkatan Jumlah Produksi Hasil Tembakau dan Penurunan Jumlah Perusahaan (April 5, 2015).

Statistik Perkebunan Indonesia (Tree Crop Estate Statistic of Indonesia) 2010-2011: Tembakau. Kementerian Pertanian, 2011

Sussman, S.; Pokhrel, P.; Black, D.; Kohrman, M.; Hamann, S.; Vateesatokit, P.; Nsimba, S.E.D. Tobacco control in developing countries: Tanzania, Nepal, China and Thailand as examples. Nicotone Tob. Res. 2007, 9, S447-S457. Switzerland, 2010.

TCSC, "Policy Paper: Indonesia dan Framework Convention on Tobacco Control", 2011, hlm. 1. 
"The Global Tobacco Economy : A Snapshot of The Economies of Multinational Tobacco Companies and of International Tobacco Control Efforts in 2008." Physicians for a Smoke-Free Canada, 2009: 3.

Tobacco Control Support Center Ikatan Ahli Kesehatan Masyarakat Indonesia. Bunga Rampai

Fakta Tembakau dan Permasalahannya di Indonesia Tahun 2012. Jakarta: Balitbang Kementerian Kesehatan RI, 2012.

WHO Framework Convention on Tobacco Control, Fifty-Sixth World Health Assembly, 21 May 2003 (Diambil dari naskah asli FCTC)

WHO, "key fact of Tobacco", updated July 2013, http://www.who.int/mediacentre/factsheets/fs339/en/ diakses tanggal 20 Mei 2014

Widyantoro Suhendar, Peranan Produk Tembakau dalam Meningkatkan Perekonomian Indonesia, Malang: Universitas Brawijaya, hlm. 11

Wipfli, H.; Stillman, F.; Tamplin, S.; Luiza de Costa e Silva, V. Achieving the Framework Convention on Tobacco Control's potential by investing in national capacity. Tob. Control 2004, 13, 433-437.

World Health Organisation (WHO). Global Progress Report on Implementation of the WHO Framework Convention on Tobacco Control; World Health Organisation: Geneva, Switzerland, 2010.

Ditanya Soal FCTC Presiden Masih Diam, http://m.beritasatu.com/nasional/280734ditanya-soal-fctc-presiden-masih-diam.html diakses tanggal 19 Juni 2015 pukul 23:48 WIB

Pemerintah Akan Tandatangani FCTC Tahun 2020, http://m.beritasatu.com/kesra/187161-pemerintah-akan-tandatangani-fctc-tahun2020.html tanggal 18 Juni 2015 pukul 2:39 WIB 